\title{
$\mathbf{L i}_{4} \mathbf{T i}_{5} \mathbf{O}_{12}$ Heattreated under Nitrogen Ambient with Outstanding Rate Capabilities
}

\author{
Rui Xu, ${ }^{1}$ Junrong Li, ${ }^{2}$ Zilong Tang, ${ }^{1}$ and Zhongtai Zhang1 \\ ${ }^{1}$ State Key Laboratory of New Ceramics and Fine Processing, Department of Materials Science and Engineering of \\ Tsinghua University, Beijing 100084, China \\ ${ }^{2}$ China Astronaut Center, Beijing 100094, China
}

Correspondence should be addressed to Zilong Tang, tzl@tsinghua.edu.cn

Received 1 June 2010; Revised 12 September 2010; Accepted 28 September 2010

Academic Editor: Quanqin Dai

Copyright (C) 2011 Rui Xu et al. This is an open access article distributed under the Creative Commons Attribution License, which permits unrestricted use, distribution, and reproduction in any medium, provided the original work is properly cited.

\begin{abstract}
The powders of spinel $\mathrm{Li}_{4} \mathrm{Ti}_{5} \mathrm{O}_{12}$ were prepared by heat treating the mixture of rutile $\mathrm{TiO}_{2}$ and $\mathrm{Li}$ acetate at $800^{\circ} \mathrm{C}$ for $3 \mathrm{~h}$ under a nitrogen atmosphere and, for comparison, under air as well. The powders heated under $\mathrm{N}_{2}$ show a remarkably higher-rate capability and better cycle stability. The discharge capacity of $\mathrm{Li}_{4} \mathrm{Ti}_{5} \mathrm{O}_{12}$ heated under $\mathrm{N}_{2}$ at $19^{\circ} \mathrm{C}$ (corresponding to a 3.2-minute total discharge) reached $107 \mathrm{~mA} \mathrm{~h} \mathrm{~g}^{-1}, 22 \mathrm{~mA} \mathrm{~h} \mathrm{~g}^{-1}$ higher than that of $\mathrm{Li}_{4} \mathrm{Ti}_{5} \mathrm{O}_{12}$ heated under air, which was $85 \mathrm{~mA} \mathrm{~h} \mathrm{~g}^{-1}$. The former material also shows a much better cycle stability, with no discharge capacity loss after 300 cycles at $6^{\circ} \mathrm{C}$ or $16.3^{\circ} \mathrm{C}$. The results indicate that heat treatment under low-oxygen partial pressure atmosphere such as $\mathrm{N}_{2}$ could significantly improve the high-rate performance of spinel $\mathrm{Li}_{4} \mathrm{Ti}_{5} \mathrm{O}_{12}$.
\end{abstract}

\section{Introduction}

There has been increasing interest in developing spinel lithium titanate $\left(\mathrm{Li}_{4} \mathrm{Ti}_{5} \mathrm{O}_{12}\right)$ as a potential anode for application in lithium ion rechargeable batteries [1-14] due to its long cycle life, excellent lithium ion intercalation and deintercalation reversibility, and "zero-strain" intercalation characteristics. Spinel $\mathrm{Li}_{4} \mathrm{Ti}_{5} \mathrm{O}_{12}$ has a main discharge plateau of about $1.55 \mathrm{~V}$ versus lithium, which makes it a very promising anode material for many lithium ion batteries using high-voltage materials such as $\mathrm{LiCoO}_{2}$ and $\mathrm{LiMnO}_{2}$ as their cathodes. However, although spinel $\mathrm{Li}_{4} \mathrm{Ti}_{5} \mathrm{O}_{12}$ exhibits no structural change during charge/discharge process, its electron conductivity is low [15]. This affects its rate capability and cycle stability, for which the experimental values are not nearly as good as the theoretical ones. In order to increase $\mathrm{Li}_{4} \mathrm{Ti}_{5} \mathrm{O}_{12}$ conductivity, several strategies have been taken, including incorporating a conducting second phase such as $\mathrm{Ag}$ [16], $\mathrm{Cu}$ [17], $\mathrm{CuO}_{x}$ [18], or $\mathrm{Li}_{2} \mathrm{CuTi}_{3} \mathrm{O}_{8}$ [19], doping with alien-valent metal ions such as $\mathrm{Ta}^{5+}[20]$ or $\mathrm{Al}^{3+}[21]$, and synthesizing nanosized $[22,23] \mathrm{Li}_{4} \mathrm{Ti}_{5} \mathrm{O}_{12}$. Another effective method is heat treating $\mathrm{Li}_{4} \mathrm{Ti}_{5} \mathrm{O}_{12}$ under a reduced or low-oxygen partial pressure atmosphere [24].
In this work, the electrochemical characteristics of $\mathrm{Li}_{4} \mathrm{Ti}_{5} \mathrm{O}_{12}$ heat treated under $\mathrm{N}_{2}$ atmosphere were studied, with emphasis on their high-rate properties. X-ray diffraction (XRD) analysis, scanning electron microscopy (SEM) observations, and galvanostatic discharge/charge tests were used to characterize the material.

\section{Experimental}

Spinel $\mathrm{Li}_{4} \mathrm{Ti}_{5} \mathrm{O}_{12}$ powders were prepared by using $9 \mathrm{~g}$ commercially available rutile $\mathrm{TiO}_{2}$ (AR) and $12 \mathrm{~g} \mathrm{Li}$ acetate (AR) [25]. The starting materials were thoroughly mixed in ethanol solvent and dried at $100^{\circ} \mathrm{C}$ for $7 \mathrm{~h}$. The dried and mixed product was then heated at $800^{\circ} \mathrm{C}$ for $3 \mathrm{~h}$ under air or $\mathrm{N}_{2}$ atmosphere, followed by natural cooling in the furnace.

The morphologies of the as-prepared powders were characterized by scanning electron microscopy (SEM) performed on Hitachi S4500. Powder X-ray diffraction (XRD) was performed on a Rigaku D/max-RB diffractometer operating in transmission mode with $\mathrm{Cu}$ Ka radiation $(\lambda=1.5418 \AA)$. The BET-specific surface area was measured with a Quantachrome NOVA 4000 system, using the $\mathrm{N}_{2}$ absorptiondesorption method at liquid nitrogen temperature. 


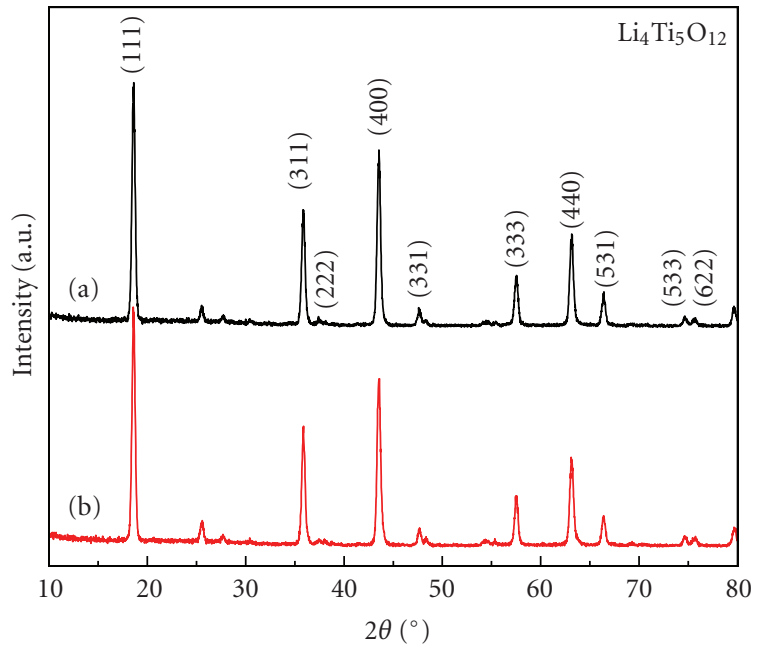

FIGURE 1: X-ray diffraction patterns of $\mathrm{Li}_{4} \mathrm{Ti}_{5} \mathrm{O}_{12}$ heat treated under (a) $\mathrm{N}_{2}$ and (b) air.

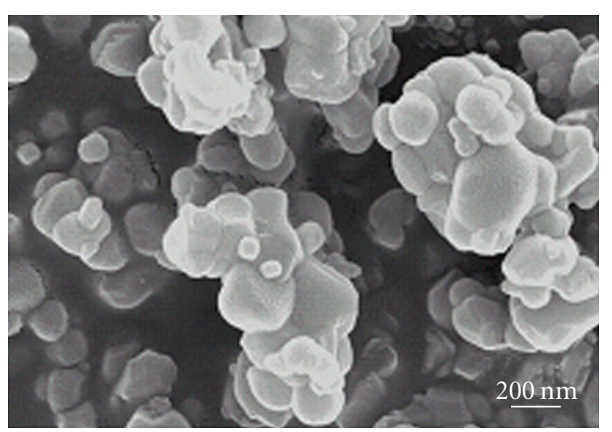

(a)

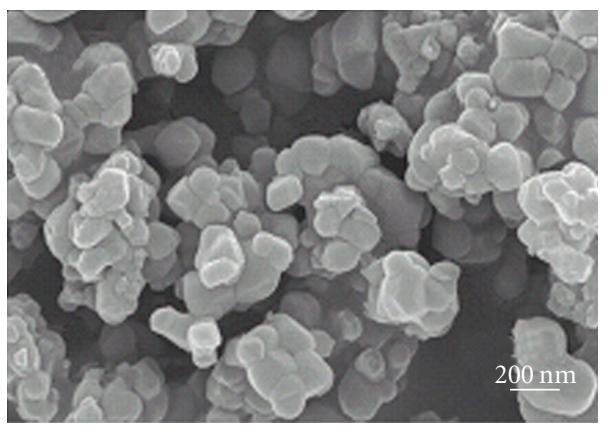

(b)

Figure 2: SEM images of $\mathrm{Li}_{4} \mathrm{Ti}_{5} \mathrm{O}_{12}$ heat treated under (a) air and (b) $\mathrm{N}_{2}$.

To fabricate the cathodes for the battery test cells, the as-prepared $\mathrm{Li}_{4} \mathrm{Ti}_{5} \mathrm{O}_{12}$ powders, Super $\mathrm{P}$ carbon black, and polyvinylidene fluoride (PVDF) binder were mixed homogeneously in a weight ratio of $80: 10: 10$ in an N-methyl pyrrolidinone (NMP) solvent. The electrode films, which used carbon-covered aluminum foil as the current collector, were fabricated using the tape-casting method [23]. The loading of active material was $1-2 \mathrm{mg} \mathrm{cm}^{-2}$. The coin-type half cell (CR2032 size) contained the as-fabricated electrode film, a lithium metal counter electrode, a microporous polyethylene separator, and electrolyte of a $1 \mathrm{M}$ solution of $\mathrm{LiPF}_{6}$ in ethylene carbonate/dimethyl carbonate (EC/DMC) ( $1: 1 \mathrm{vol} \%$; Merck). The cell was constructed and handled in an Ar-filled vacuum glove box.

The discharge/charge tests were carried out using a LAND Celltest 2001 A (Wuhan, China) system between 2.5 and $1 \mathrm{~V}$ versus the Li counter electrode. First, the test cell was discharged for $\mathrm{Li}^{+}$ions to intercalate into the cathode, and then the test cell was charged and held at $2.5 \mathrm{~V}$ to fully charge before discharge. The constant current charge and discharge rates are the same. Cyclic voltammogram was recorded from 1.0 to $2.5 \mathrm{~V}$ at a scan rate of $10 \mathrm{mV} \mathrm{s}^{-1}$, using IM6e electrochemical workstation (Germany).

\section{Results and Discussion}

Figure 1 shows the XRD patterns of as-prepared $\mathrm{Li}_{4} \mathrm{Ti}_{5} \mathrm{O}_{12}$ powders after heat treatment under air or $\mathrm{N}_{2}$ atmosphere at $800^{\circ} \mathrm{C}$ for $3 \mathrm{~h}$. The diffraction peaks of both samples can be indexed as spinel lithium titanate (cubic phase, space group $\mathrm{Fd} 3 \mathrm{~m}$ space group), except two small peaks at around $25^{\circ}$ and $55^{\circ}$ which probably correspond to remaining unreacted $\mathrm{TiO}_{2}$. The only difference between the two XRD patterns is that the diffraction peaks for the sample heated under $\mathrm{N}_{2}$ are slightly shifted to the lower $2 \theta$ values compared to the one heated under air. This indicates that the lattice parameter of the former is larger than that of the latter. This is in good agreement with previous results of $\mathrm{Li}_{4} \mathrm{Ti}_{5} \mathrm{O}_{12}$ heat treated under $\mathrm{H}_{2} / \mathrm{Ar}$ atmosphere [24]. The larger lattice parameter for $\mathrm{Li}_{4} \mathrm{Ti}_{5} \mathrm{O}_{12}$ powders heat treated under $\mathrm{N}_{2}$ atmosphere could be attributed to the reduction of some $\mathrm{Ti}^{4+}$ ions into $\mathrm{Ti}^{3+}$ when heated under low-oxygen partial pressure atmosphere, as the sizes of $\mathrm{Ti}^{3+}$ ions are larger than those of $\mathrm{Ti}^{4+}$. The presence of $\mathrm{Ti}^{3+}$ ions could also explain the darker color of $\mathrm{Li}_{4} \mathrm{Ti}_{5} \mathrm{O}_{12}$ powders heat treated under $\mathrm{N}_{2}$ atmosphere, which is light yellow (while the sample heated under air is white). It is believed that the reduction of some $\mathrm{Ti}^{4+}$ ions into $\mathrm{Ti}^{3+}$ is ascribed to the increase in electron concentration, which results from nonstoichiometry of $\mathrm{Li}_{4} \mathrm{Ti}_{5} \mathrm{O}_{12}$ at lowoxygen partial pressures.

$$
\mathrm{O}_{o}^{x} \longrightarrow \frac{1}{2} \mathrm{O}_{2}(g)+V_{o}^{\bullet \bullet}+2 e^{\prime} .
$$

This relatively high electron concentration of $\mathrm{Li}_{4} \mathrm{Ti}_{5} \mathrm{O}_{12}$ treated under reducing or low-oxygen partial pressure atmosphere compared to that of $\mathrm{Li}_{4} \mathrm{Ti}_{5} \mathrm{O}_{12}$ treated under air has been noted in previous works $[20,24]$.

The SEM images of the two samples are shown in Figure 2. The diameter of the $\mathrm{Li}_{4} \mathrm{Ti}_{5} \mathrm{O}_{12}$ particle treated under air (Figure 2(a)) was almost the same as that treated under $\mathrm{N}_{2}$ atmosphere (Figure 2(b)), in agreement with BET-specific surface areas of the two samples, which are $3.70 \mathrm{~m}^{2} \mathrm{~g}^{-1}$ and $3.78 \mathrm{~m}^{2} \mathrm{~g}^{-1}$, respectively.

The charge/discharge properties and rate capabilities of the test cells containing $\mathrm{Li}_{4} \mathrm{Ti}_{5} \mathrm{O}_{12}$ heat treated under air or $\mathrm{N}_{2}$ atmosphere as the electrode material were tested and analyzed. A comparison of the rate capabilities of the test cells is shown in Figure 3(a); the data shows that extremely 


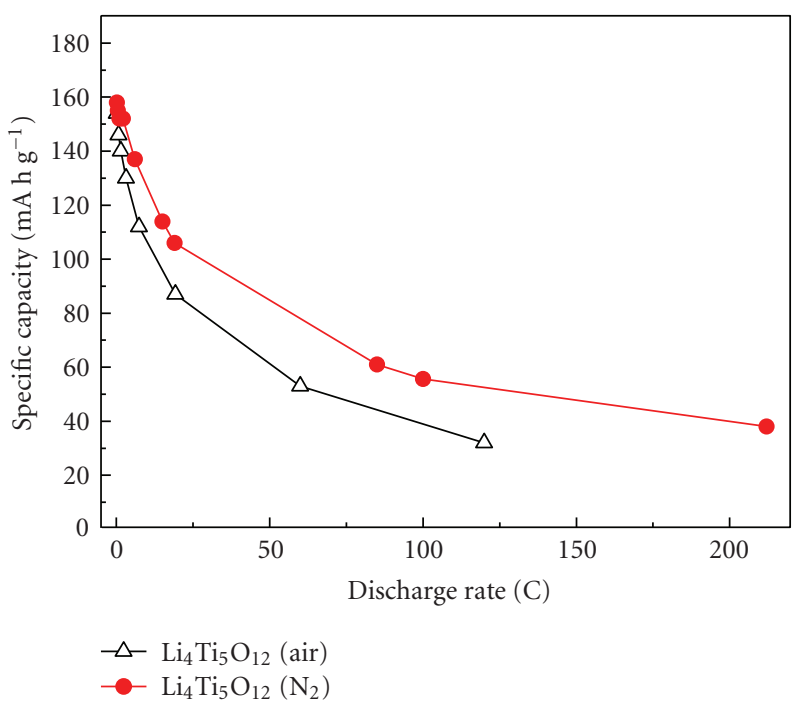

(a)

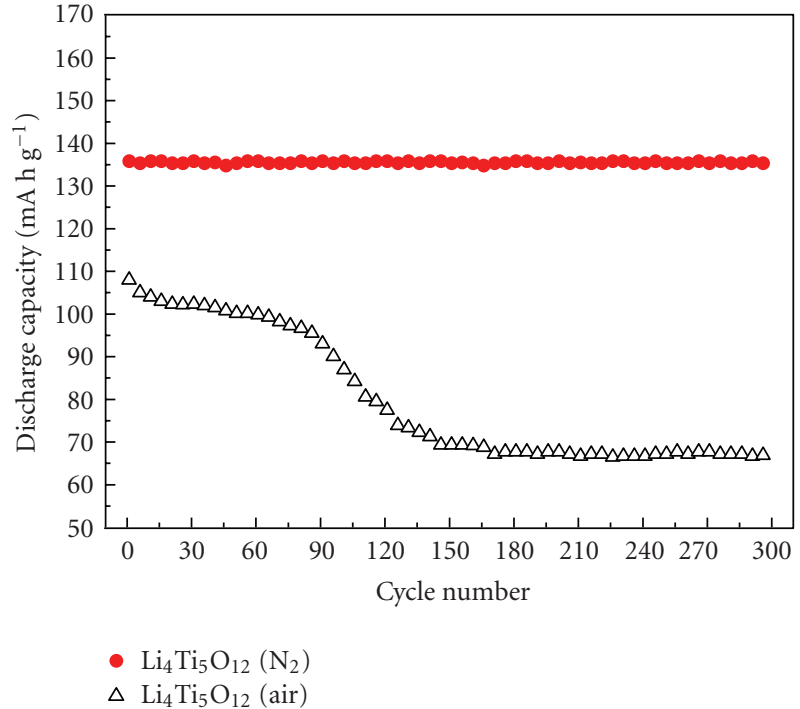

(b)

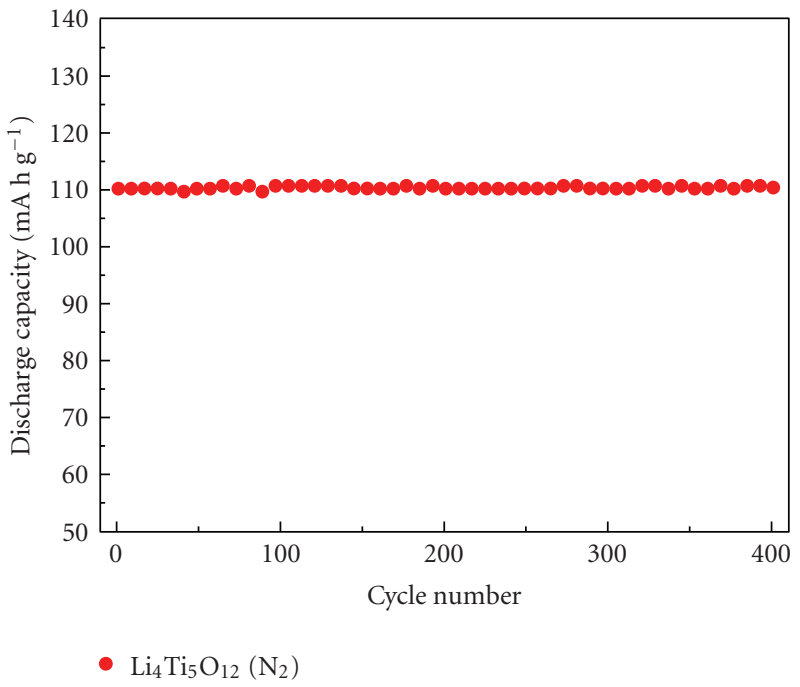

(c)

FIgURE 3: Electrochemical properties of $\mathrm{Li}_{4} \mathrm{Ti}_{5} \mathrm{O}_{12}$ heat treated under air or $\mathrm{N}_{2}$ ambient. (a) Discharge capacity of the two samples under various rates. (b) Capacity retentions of the two samples when performing full charge/discharge cycles at $6 \mathrm{C}$. (c) Capacity retentions of $\mathrm{Li}_{4} \mathrm{Ti}_{5} \mathrm{O}_{12}$ heat treated under $\mathrm{N}_{2}$ ambient when performing full charge/discharge cycles at $16.3 \mathrm{C}$.

high rates can be achieved for $\mathrm{Li}_{4} \mathrm{Ti}_{5} \mathrm{O}_{12}$ heat treated under $\mathrm{N}_{2}$ atmosphere. It can be seen that at low discharge rates $(<0.5 \mathrm{C})$, the specific capacities of the two test cells are very close. As the discharge rate increases, the capacity of the $\mathrm{Li}_{4} \mathrm{Ti}_{5} \mathrm{O}_{12}$ heat treated under $\mathrm{N}_{2}$ atmosphere is remarkably higher than that heated under air. The former could reach a discharge capacity of $107 \mathrm{~mA} \mathrm{~h} \mathrm{~g}^{-1}$ at $19 \mathrm{C}\left(1680 \mathrm{mAg}^{-1}\right.$ of current density), $22 \mathrm{~mA} \mathrm{~h} \mathrm{~g}^{-1}$ higher than the latter, which had a discharge capacity of only $85 \mathrm{mAh} \mathrm{g}^{-1}$. At a $85 \mathrm{C}$ rate $\left(4920 \mathrm{~mA} \mathrm{~g}^{-1}\right.$ of current density), a capacity of more than $60 \mathrm{~mA} \mathrm{~h} \mathrm{~g}^{-1}$ could still be obtained, and a capacity of nearly $40 \mathrm{~mA} \mathrm{~h} \mathrm{~g}^{-1}$ was achieved at a $212 \mathrm{C}\left(8240 \mathrm{~mA} \mathrm{~g}^{-1}\right.$ of current density) rate for the $\mathrm{Li}_{4} \mathrm{Ti}_{5} \mathrm{O}_{12}$ heat treated under $\mathrm{N}_{2}$ atmosphere. This result is within expectations because the $\mathrm{Li}_{4} \mathrm{Ti}_{5} \mathrm{O}_{12}$ heat treated under $\mathrm{N}_{2}$ atmosphere has an increased electron concentration. The comparison of the rate capabilities of the test cells confirms that the heat treatment under $\mathrm{N}_{2}$ atmosphere for $\mathrm{Li}_{4} \mathrm{Ti}_{5} \mathrm{O}_{12}$ can largely improve its rate capability.

The change in discharge capacities with cycle numbers of the two samples at a $6 \mathrm{C}$ rate $\left(800 \mathrm{~mA} \mathrm{~g}^{-1}\right.$ of current density) is shown in Figure 3(b), respectively. It shows that the cycling performance of the $\mathrm{Li}_{4} \mathrm{Ti}_{5} \mathrm{O}_{12}$ heat treated under $\mathrm{N}_{2}$ atmosphere is much better than that heat treated under air. After charging/discharging at $6 \mathrm{C}$ for 300 cycles, the former sample still remains $100 \%$ in discharge capacity, showing $135 \mathrm{mAhg}^{-1}$, while the latter sample capacity slowly fades as the cycle number increases and quickly drops 


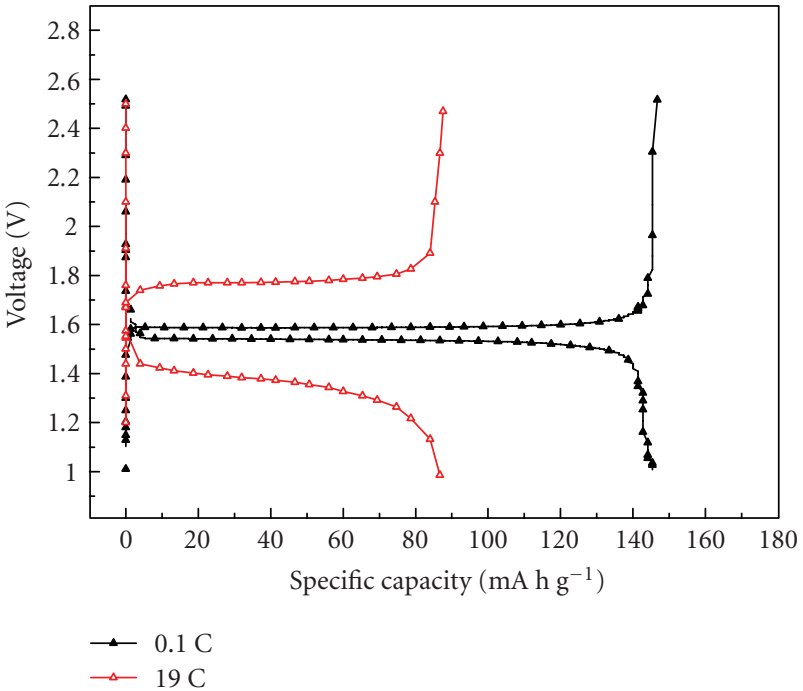

(a)

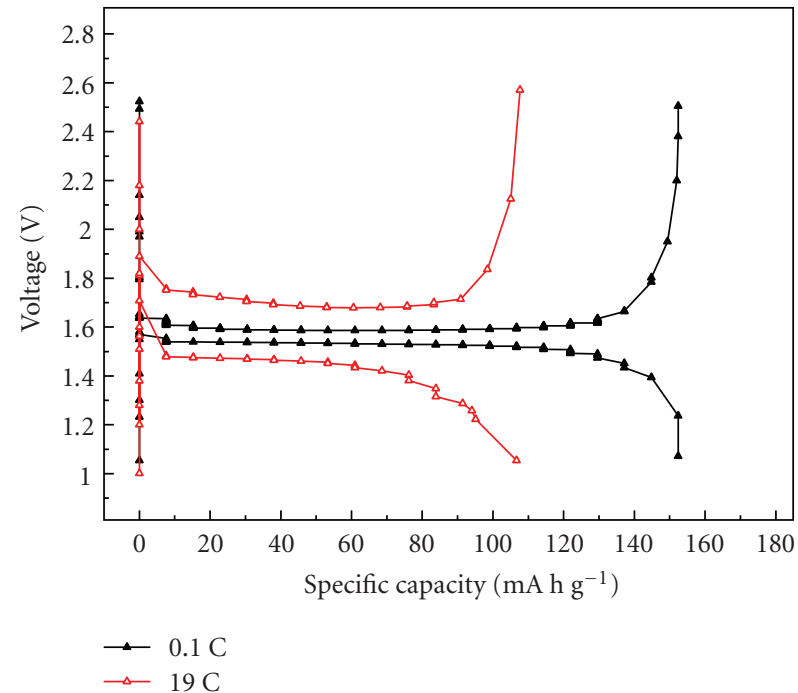

(b)

Figure 4: Charge discharge performance $(0.1 \mathrm{C})$ of $\mathrm{Li}_{4} \mathrm{Ti}_{5} \mathrm{O}_{12}$ heat treated under (a) air and (b) $\mathrm{N}_{2}$.

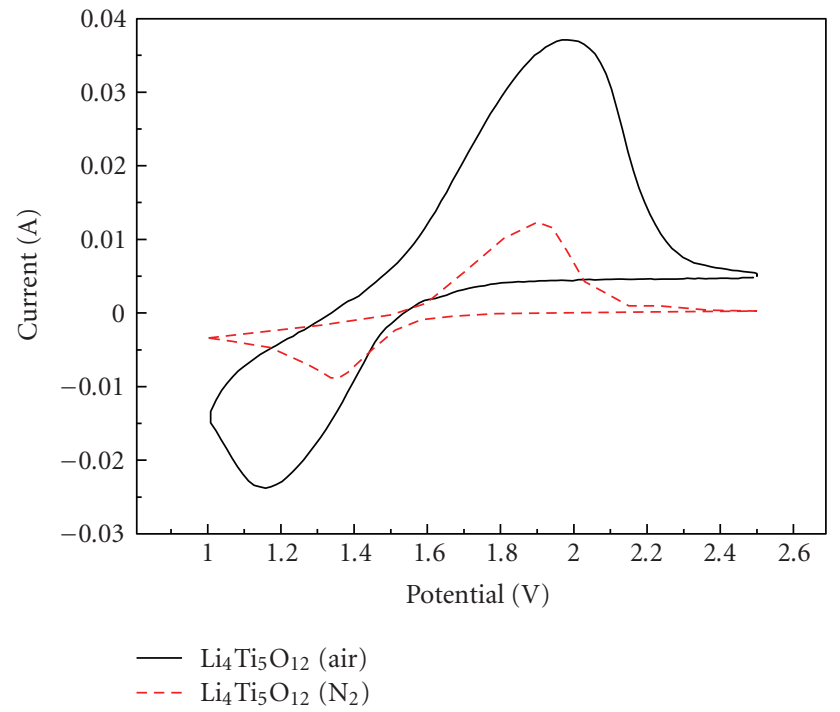

Figure 5: Cyclic voltammograms of test cells containing $\mathrm{Li}_{4} \mathrm{Ti}_{5} \mathrm{O}_{12}$ heat treated under air or $\mathrm{N}_{2}$ atmosphere as cathode materials at scan rate of $10 \mathrm{mV} \mathrm{s}^{-1}$.

after 90 cycles. After about 140 cycles, the discharge capacity retention of the $\mathrm{Li}_{4} \mathrm{Ti}_{5} \mathrm{O}_{12}$ heat treated under air is only $68 \%$, showing $67 \mathrm{~mA} \mathrm{~h} \mathrm{~g}^{-1}$. The high-rate cycling stability for the $\mathrm{Li}_{4} \mathrm{Ti}_{5} \mathrm{O}_{12}$ heat treated under $\mathrm{N}_{2}$ atmosphere at $16.3 \mathrm{C}$ ( $1650 \mathrm{~mA} \mathrm{~g}^{-1}$ of current density) is also excellent. As shown in Figure 3(c), it keeps $100 \%$ in discharge capacity after 400 cycles, showing $109 \mathrm{~mA} \mathrm{~h} \mathrm{~g}^{-1}$. From these results, it can be concluded that heat treatment under a reducing atmosphere such as $\mathrm{N}_{2}$ could not only improve $\mathrm{Li}_{4} \mathrm{Ti}_{5} \mathrm{O}_{12}$ high-rate capability significantly, but could also greatly enhance its cycling stability at high rates.
Figure 4 shows the charge/discharge curves for the test cells at $0.1 \mathrm{C}\left(7 \mathrm{~mA} \mathrm{~g}^{-1}\right.$ of current density) and $19 \mathrm{C}$ ( $1680 \mathrm{~mA} \mathrm{~g}^{-1}$ of current density). When comparing the voltage profile of $\mathrm{Li}_{4} \mathrm{Ti}_{5} \mathrm{O}_{12}$ heat treated under $\mathrm{N}_{2}$ atmosphere with the one of that heat treated under air, it can be seen that the former sample has more sloping charge/discharge curves. This indicates that the $\mathrm{Li}_{4} \mathrm{Ti}_{5} \mathrm{O}_{12}$ heat treated under $\mathrm{N}_{2}$ has a more evident pseudocapacitive faradaic kinetics, which is due to its higher electron conductivity. From Figure 4, it can be observed that when charging and discharging at a rate of $0.1 \mathrm{C}$, the capacity and plateau voltage of the two cells were very close: around $150 \mathrm{~mA} \mathrm{~h} \mathrm{~g}^{-1}$ and $1.60 \mathrm{~V}$, respectively. At $19 \mathrm{C}$, the capacity of the $\mathrm{Li}_{4} \mathrm{Ti}_{5} \mathrm{O}_{12}$ heat treated under air was much smaller than that of the $\mathrm{Li}_{4} \mathrm{Ti}_{5} \mathrm{O}_{12}$ heat treated under $\mathrm{N}_{2}$. At 19 C, both test cells have more sloping voltage profiles than at $0.1 \mathrm{C}$, indicating a more evident surface-confined charge-transfer kinetics (known as the pseudocapacitive faradaic kinetics) existing along with diffusion-controlled kinetics as lithium intercalating/deintercalating in $\mathrm{Li}_{4} \mathrm{Ti}_{5} \mathrm{O}_{12}$. Due to their higher polarization under higher rates, both cells charge plateau voltages are higher than those charging at low rates, and meanwhile the discharge plateau voltages are lower.

Cyclic voltammogram was recorded, as shown in Figure 5 , from 1.0 to $2.5 \mathrm{~V}$ at a scan rate as high as $10 \mathrm{mV} \mathrm{s}^{-1}$. The two samples both have broad redox peaks under a high scan rate, which is in good agreement with the sloping voltage profile during the galvanostatic discharge/charge cycles at high rates, indicating a concurrence of both pseudocapacitive lithium intercalation mechanism and diffusioncontrolled kinetics during the process. The two redox peaks of the $\mathrm{Li}_{4} \mathrm{Ti}_{5} \mathrm{O}_{12}$ heat treated under $\mathrm{N}_{2}$ atmosphere appear at $1.35 \mathrm{~V}$ and $1.9 \mathrm{~V}$ (versus $\mathrm{Li}^{+} / \mathrm{Li}$, depending on the scan rate), while those of $\mathrm{Li}_{4} \mathrm{Ti}_{5} \mathrm{O}_{12}$ heat treated under air appear at $1.15 \mathrm{~V}$ and $2.0 \mathrm{~V}$. The results show that under a high charge/discharge rate, the $\mathrm{Li}_{4} \mathrm{Ti}_{5} \mathrm{O}_{12}$ heat treated under $\mathrm{N}_{2}$ 
atmosphere has relatively low polarization compared to that heat treated under air, which results from its higher electron concentration. This lower polarization under high charge/discharge rates of the $\mathrm{Li}_{4} \mathrm{Ti}_{5} \mathrm{O}_{12}$ heat treated under $\mathrm{N}_{2}$ atmosphere leads to its better rate capability.

\section{Conclusions}

The spinel $\mathrm{Li}_{4} \mathrm{Ti}_{5} \mathrm{O}_{12}$ powders were prepared by heat treating the mixture of rutile $\mathrm{TiO}_{2}$ and $\mathrm{Li}$ acetate under nitrogen atmosphere, and, for comparison, under air. The two samples have similar particle size and specific surface area, but the powders heated under $\mathrm{N}_{2}$ showed better rate capability and cycle stability in comparison with those heated under air. The discharge capacity of $\mathrm{Li}_{4} \mathrm{Ti}_{5} \mathrm{O}_{12}$ heated under air at $19 \mathrm{C}$ was $85 \mathrm{mAhg}^{-1}$, while the capacity of $\mathrm{Li}_{4} \mathrm{Ti}_{5} \mathrm{O}_{12}$ heated under $\mathrm{N}_{2}$ reached $107 \mathrm{~mA} \mathrm{~h} \mathrm{~g}^{-1}$. Meanwhile, the cycle stability of the $\mathrm{Li}_{4} \mathrm{Ti}_{5} \mathrm{O}_{12}$ heated under $\mathrm{N}_{2}$ was also much better than that of the sample heated under air, indicating that heat treatment under reducing or low-oxygen partial pressure atmosphere such as $\mathrm{N}_{2}$ could greatly improve the high-rate performance of spinel $\mathrm{Li}_{4} \mathrm{Ti}_{5} \mathrm{O}_{12}$.

\section{Acknowledgments}

R. Xu thanks F. Y. Kang, L. Zou, and X. Fan for the help with electrochemical workstation for cyclic voltammogram measurements and AC impedance measurements. Language revision help from $\mathrm{H}$. Howard is gratefully acknowledged. The Support from the Natural Science Foundation of China (no. 50602050) and the National High Technology Research and Development Program of China (863 Program, no. 2007AA03Z235) is gratefully acknowledged.

\section{References}

[1] T. Ohzuku, A. Ueda, N. Yamamoto, and Y. Iwakoshi, "Factor affecting the capacity retention of lithium-ion cells," Journal of Power Sources, vol. 54, no. 1, pp. 99-102, 1995.

[2] K. M. Colbow, J. R. Dahn, and R. R. Haering, "Structure and electrochemistry of the spinel oxides $\mathrm{LiTi}_{2} \mathrm{O}_{4}$ and $\mathrm{Li}^{3 / 4} \mathrm{Ti}^{5 / 3} \mathrm{O}_{4}$," Journal of Power Sources, vol. 26, no. 3, pp. 397402, 1989.

[3] K. Zaghib, M. Simoneau, M. Armand, and M. Gauthier, "Electrochemical study of $\mathrm{Li}_{4} \mathrm{Ti}_{5} \mathrm{O}_{12}$ as negative electrode for Li-ion polymer rechargeable batteries," Journal of Power Sources, vol. 81-82, pp. 300-305, 1999.

[4] A. Guerfi, S. Sévigny, M. Lagacé, P. Hovington, K. Kinoshita, and $\mathrm{K}$. Zaghib, "Nano-particle $\mathrm{Li}_{4} \mathrm{Ti}_{5} \mathrm{O}_{12}$ spinel as electrode for electrochemical generators," Journal of Power Sources, vol. 119, pp. 88-94, 2003.

[5] T. Ohzuku, A. Ueda, and N. Yamamoto, "Zero-strain insertion material of $\mathrm{Li}\left[\mathrm{Li}_{1 / 3} \mathrm{Ti}_{5 / 3}\right] \mathrm{O}_{4}$ for rechargeable lithium cells," Journal of the Electrochemical Society, vol. 142, no. 5, pp. 14311435, 1995.

[6] M. M. Thackeray, "Structural considerations of layered and spinel lithiated oxides for lithium ion batteries," Journal of the Electrochemical Society, vol. 142, no. 8, pp. 2558-2563, 1995.
[7] E. Ferg, R. J. Gummow, A. de Kock, and M. M. Thackeray, "Spinel anodes for lithium-ion batteries," Journal of the Electrochemical Society, vol. 141, no. 11, pp. L147-L150, 1994.

[8] T. Ohzuku, Y. Iwakoshi, and K. Sawai, "Formation of lithiumgraphite intercalation compounds in nonaqueous electrolytes and their application as a negative electrode for a lithium ion (shuttlecock) cell," Journal of the Electrochemical Society, vol. 140, no. 9, pp. 2490-2497, 1993.

[9] K. Zaghib, M. Armand, and M. Gauthier, "Electrochemistry of anodes in solid-state Li-ion polymer batteries," Journal of the Electrochemical Society, vol. 145, no. 9, pp. 3135-3140, 1998.

[10] S. Scharner, W. Weppner, and P. Schmid-Beurmann, "Evidence of two-phase formation upon lithium insertion into the $\mathrm{Li}_{1.33} \mathrm{Ti}_{1.67} \mathrm{O}_{4}$ spinel," Journal of the Electrochemical Society, vol. 146, no. 3, pp. 857-861, 1999.

[11] D. Peramunage and K. M. Abraham, "Preparation of micronsized $\mathrm{Li}_{4} \mathrm{Ti}_{5} \mathrm{O}_{12}$ and its electrochemistry in polyacrylonitrile electrolyte-based lithium cells," Journal of the Electrochemical Society, vol. 145, no. 8, pp. 2609-2615, 1998.

[12] S. Huang, Z. Wen, X. Zhu, and X. Yang, "Research on $\mathrm{Li}_{4} \mathrm{Ti}_{5} \mathrm{O}_{12} / \mathrm{Cu}_{x} \mathrm{O}$ composite anode materials for lithium-ion batteries," Journal of the Electrochemical Society, vol. 152, no. 7, pp. A1301-A1305, 2005.

[13] V. S. Hernandez, "Stoichiometry, structures and polymorphism of spinel-like phases, $\mathrm{Li}_{1.33 \mathrm{x}} \mathrm{Zn}_{2-2 \mathrm{x}} \mathrm{Ti}_{1+0.67 \mathrm{x}} \mathrm{O}_{4}$," Journal of Materials Chemistry, vol. 6, no. 9, pp. 1533-1536, 1996.

[14] M. M. Thackeray, P. J. Johnson, L. A. de Picciotto, P. G. Bruce, and J. B. Goodenough, "Electrochemical extraction of lithium from $\mathrm{LiMn}_{2} \mathrm{O}_{4}$," Materials Research Bulletin, vol. 19, no. 2, pp. 179-187, 1984.

[15] A. Guerfi, P. Charest, K. Kinoshita, M. Perrier, and K. Zaghib, "Nano electronically conductive titanium-spinel as lithium ion storage negative electrode," Journal of Power Sources, vol. 126, no. 1-2, pp. 163-168, 2004.

[16] S. Huang, Z. Wen, X. Zhu, and Z. Gu, "Preparation and electrochemical performance of Ag doped $\mathrm{Li}_{4} \mathrm{Ti}_{5} \mathrm{O}_{12}$," Electrochemistry Communications, vol. 6, no. 11, pp. 1093-1097, 2004.

[17] S. Huang, Z. Wen, B. Lin, J. Han, and X. Xu, "The high-rate performance of the newly designed $\mathrm{Li}_{4} \mathrm{Ti}_{5} \mathrm{O}_{12} / \mathrm{Cu}$ composite anode for lithium ion batteries," Journal of Alloys and Compounds, vol. 457, no. 1-2, pp. 400-403, 2008.

[18] S. Huang, Z. Wen, X. Zhu, and X. Yang, "Research on $\mathrm{Li}_{4} \mathrm{Ti}_{5} \mathrm{O}_{12} / \mathrm{Cu}_{x} \mathrm{O}$ composite anode materials for lithium-ion batteries," Journal of the Electrochemical Society, vol. 152, no. 7, pp. A1301-A1305, 2005.

[19] D. Wang, H. -Y. Xu, M. Gu, and C. -H. Chen, " $\mathrm{li}_{2} \mathrm{CuTi}_{3} \mathrm{O}_{8}-$ $\mathrm{Li}_{4} \mathrm{Ti}_{5} \mathrm{O}_{12}$ double spinel anode material with improved rate performance for Li-ion batteries," Electrochemistry Communications, vol. 11, no. 1, pp. 50-53, 2009.

[20] J. Wolfenstine and J. L. Allen, "Electrical conductivity and charge compensation in Ta doped $\mathrm{Li}_{4} \mathrm{Ti}_{5} \mathrm{O}_{12}$," Journal of Power Sources, vol. 180, no. 1, pp. 582-585, 2008.

[21] H. Zhao, Y. Li, Z. Zhu, J. Lin, Z. Tian, and R. Wang, "Structural and electrochemical characteristics of $\mathrm{Li}_{4-x} \mathrm{Al}_{x} \mathrm{Ti}_{5} \mathrm{O}_{12}$ as anode material for lithium-ion batteries," Electrochimica Acta, vol. 53, no. 24, pp. 7079-7083, 2008.

[22] L. Kavana and M. Grätzel, "Facile synthesis of nanocrystalline $\mathrm{Li}_{4} \mathrm{Ti}_{5} \mathrm{O}_{12}$ (Spinel) exhibiting fast Li insertion," Electrochemical and Solid-State Letters, vol. 5, no. 2, pp. A39-A42, 2002.

[23] J. Li, Z. Tang, and Z. Zhang, "Controllable formation and electrochemical properties of one-dimensional nanostructured spinel $\mathrm{Li}_{4} \mathrm{Ti}_{5} \mathrm{O}_{12}$," Electrochemistry Communications, vol. 7, no. 9, pp. 894-899, 2005. 
[24] J. Wolfenstine, U. Lee, and J. L. Allen, "Electrical conductivity and rate-capability of $\mathrm{Li}_{4} \mathrm{Ti}_{5} \mathrm{O}_{12}$ as a function of heattreatment atmosphere," Journal of Power Sources, vol. 154, no. 1, pp. 287-289, 2006.

[25] J. Kim and J. Cho, "Spinel $\mathrm{Li}_{4} \mathrm{Ti}_{5} \mathrm{O}_{12}$ nanowires for high-rate Li-ion intercalation electrode," Electrochemical and Solid-State Letters, vol. 10, no. 3, pp. A81-A84, 2007. 

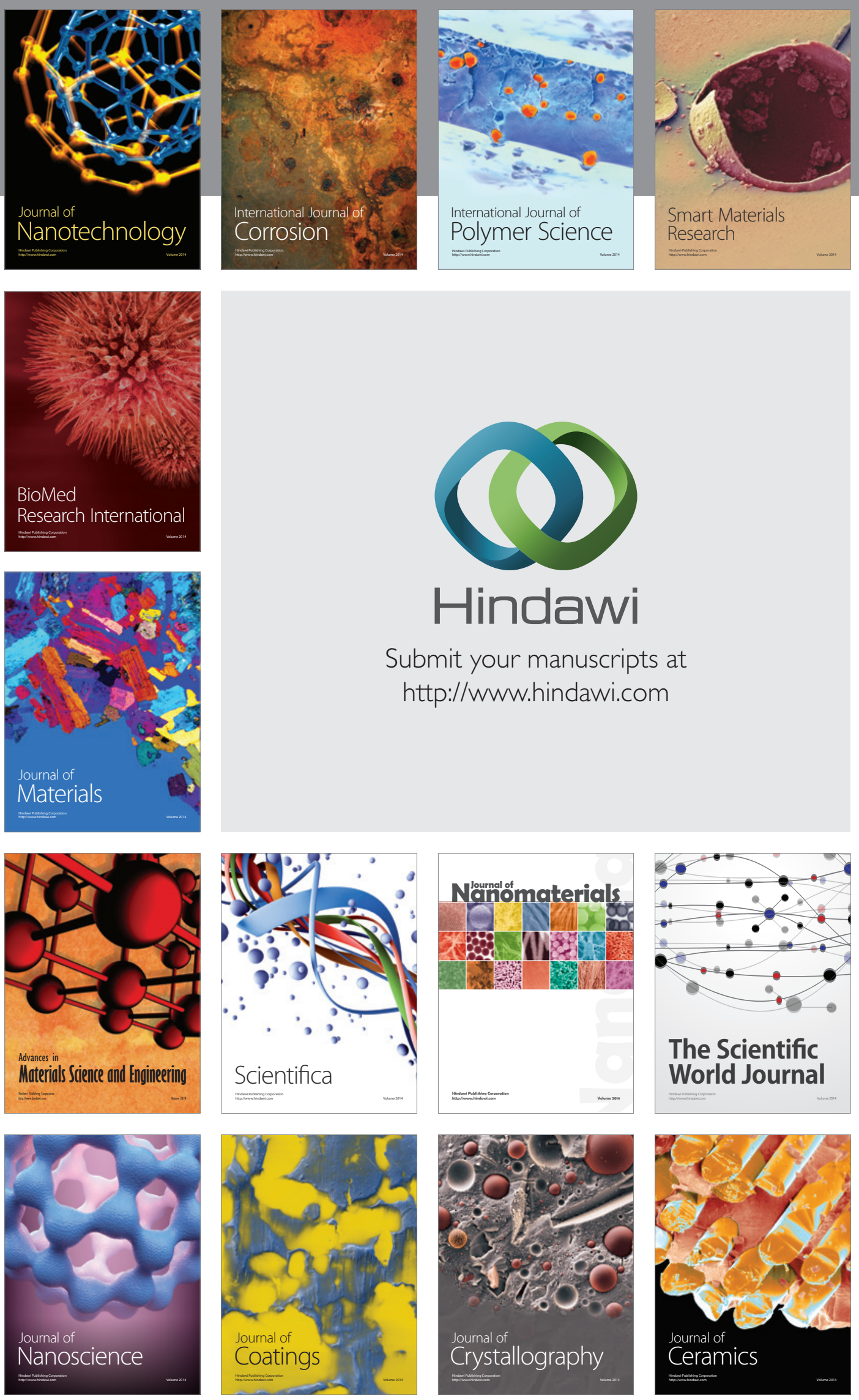

The Scientific World Journal

Submit your manuscripts at

http://www.hindawi.com

\section{World Journal}

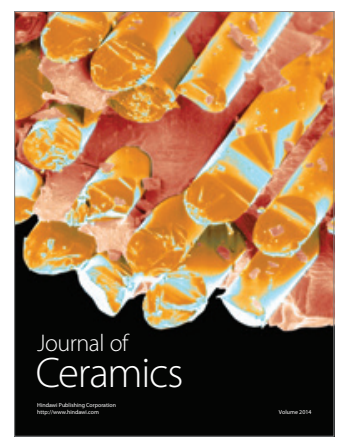

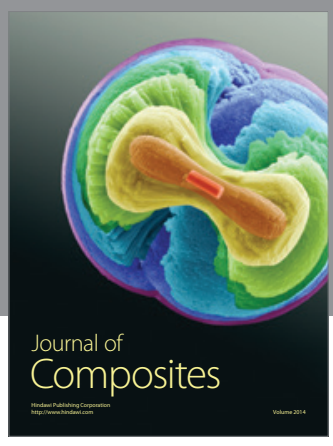
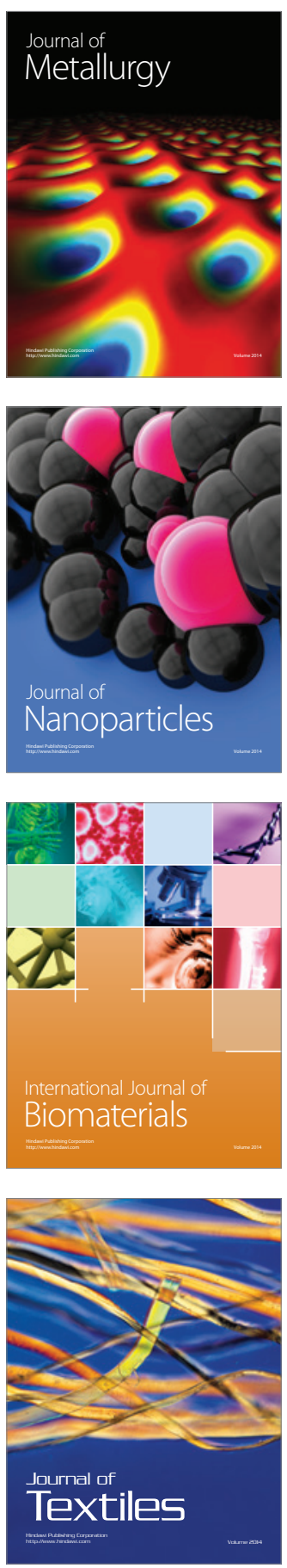